\title{
A lifetime perspective of biomass allocation in Quercus pubescens trees in a dry, alpine valley
}

\author{
Martijn Slot $\cdot$ Stijntje H. Janse-ten Klooster • \\ Frank J. Sterck - Ute Sass-Klaassen • \\ Roman Zweifel
}

Received: 13 May 2011/Revised: 24 February 2012/Accepted: 20 March 2012/Published online: 4 April 2012

(C) Springer-Verlag 2012

\begin{abstract}
Plasticity of biomass allocation is a key to growth and survival of trees exposed to variable levels of stress in their lifetime. Most of our understanding of dynamic biomass allocation comes from seedling studies, but plasticity may be different in mature trees. We used stem analysis to reconstruct whole-tree growth and biomass allocation patterns in Quercus pubescens trees harvested from a dry woodland in Valais, Switzerland. We identified three distinct growth phases. In phase I, a primary root developed but the aboveground structure did not persist. In phase II, height growth occurred and secondary roots developed. In phase III, height growth ceased and stems and roots only grew radially. Reference trees harvested from a less dry site nearby only showed phase II-type growth. In line with our hypothesis, drought-stressed trees maintained more biomass in roots and less in aboveground woody parts than reference trees. Contrary to our expectation, stressed trees allocated proportionally more
\end{abstract}

Communicated by A. Bräuning.

Electronic supplementary material The online version of this article (doi:10.1007/s00468-012-0717-4) contains supplementary material, which is available to authorized users.

M. Slot · S. H. Janse-ten Klooster · R. Zweifel

Swiss Federal Research Institute WSL, Zürcherstrasse 111, 8903 Birmensdorf, Switzerland

Present Address:

M. Slot $(\bowtie)$

Department of Biology, University of Florida, Gainesville,

FL 32611, USA

e-mail: mslot@ufl.edu

S. H. Janse-ten Klooster · F. J. Sterck · U. Sass-Klaassen Forest Ecology and Forest Management Group, Wageningen University, P.O. Box 47, 6700 AA Wageningen,

The Netherlands resources to leaves and less to roots in the growing season before harvest than reference trees. It appears that subseasonal wood anatomical adjustments to water availability minimize hydraulic failure, thus enabling these dry woodland trees to invest preferentially in leaves. Wet years did not see preferential investment in aboveground tissues, suggesting more restricted plasticity in biomass allocation in these mature trees than in seedlings. It is concluded that trees beyond seedling stage show different responses to variation in drought than the better-studied seedlings.

Keywords Biomass distribution - Dry woodland - Root/ shoot ratio $\cdot$ Stem analysis $\cdot$ Water relations

\section{Introduction}

Plasticity of biomass allocation in response to environmental stress contributes strongly to the success of plants and is, in fact, thought to be more important than plasticity in physiological traits (Weiner 2004). Plastic responses of biomass allocation to biotic and abiotic conditions enable plants to maintain functional relationships among leaves, stem and roots (Cannell and Dewar 1994; McConnaughay and Coleman 1999; Martinez-Vilalta et al. 2007). In dry woodlands, an important question is how plants allocate biomass among fine roots for water and nutrient acquisition; coarse roots, stem and branches for water transport; and leaves for transpiration and light capture.

Following the functional equilibrium hypothesis (Brouwer 1962), plants in dry conditions are expected to invest proportionally large amounts of biomass in water acquisition and transport structures. Such high investment in roots and aboveground woody tissue prevents the occurrence of harmfully low water potentials in plant tissues 
(Martinez-Vilalta et al. 2007), reduces the risk of cavitation in the xylem (Zweifel and Zeugin 2008; Galle et al. 2010), and postpones stomatal closure (Tyree and Zimmermann 2002). Plants in dry environments thus trade off high investment in water acquisition and transport against investments in leaves, leading to reduced light capture and subsequently lower growth rates (Weber et al. 2007). Given this trade-off, relief from drought stress should allow for increased investment in leaf display and light harvesting.

Our understanding of biomass allocation in response to environmental stress is primarily based on seedling studies (e.g., McConnaughay and Coleman 1999; Sack and Grubb 2002; Markesteijn and Poorter 2009). However, mature trees may behave differently than seedlings. For example, larger trees can store more reserves than seedlings (Chapin et al. 1990) and may thus not need to change biomass allocation patterns to survive episodic stress. Moreover, the capacity to acclimate to (periodic) stress conditions might be lower than that of seedlings (Niinemets 2010). Finally, in mature trees the costs of maintaining high plasticity may outweigh the benefits (DeWitt et al. 1998).

How to measure lifetime growth and biomass allocation patterns of mature trees? Stem analysis, a technique of examining the growth rings of sections from a tree trunk, is a powerful tool that can provide information on cumulative wood production within the whole woody plant (Fayle 1975; Drexhage et al. 1999). Annual increment of woody tissues can also be reconstructed and linked to environmental data. Here, stem analysis, extended to include coarse roots, is used to reconstruct whole-tree biomass allocation patterns in pubescent oak trees (Quercus pubescens Willd.) harvested from a dry woodland in the central Rhône valley (Valais) in Switzerland (hereafter referred to as 'stressed trees'). We contrasted these 'stressed trees' with individuals harvested from a nearby site that is less dry ('reference trees').

Following the functional equilibrium hypothesis, we expected that stressed trees (1) maintain proportionally more root biomass and less aboveground woody biomass than reference trees; (2) allocate more biomass to aboveground wood and less to leaves than reference trees and (3) preferentially invest in aboveground structures in years with high precipitation. To test these hypotheses we analyzed diameter increment and longitudinal growth of stems and roots and linked these data with growing season precipitation data collected at a nearby weather station.

\section{Materials and methods}

Study site

The study was carried out at two sites (Salgesch and Jeizinen) with contrasting conditions in Valais, Switzerland, an inner-alpine valley with cold winters and warm summers, and an annual precipitation of ca. $600 \mathrm{~mm}$ (Table $\mathrm{S} 1$ ). Summer months are characterized by moisture deficit, with potential evapotranspiration exceeding precipitation (Weber et al. 2007).

The stressed trees grew on a south-exposed slope near Salgesch $\left(46^{\circ} 19^{\prime} 27 \mathrm{~N}, 7^{\circ} 34^{\prime} 40 \mathrm{E}\right)$ at $975 \mathrm{~m}$ a.s.l. The soil at this site is $10-30 \mathrm{~cm}$ deep and classified as a rendzic leptosol on solid rock limestone (Rigling et al. 2002). This type of soil has low water-holding capacity. The reference trees grew near Jeizinen $\left(46^{\circ} 19^{\prime} 40 \mathrm{~N}, 7^{\circ} 34^{\prime} 40 \mathrm{E}\right)$ at $1,270 \mathrm{~m}$ a.s.l. in deeper soil $(50-130 \mathrm{~cm})$ with better water-holding capacity. This site has lower vapor pressure deficit and less negative soil water potential (Zweifel et al. 2006, 2009). Quercus pubescens (pubescent oak) is at both sites co-dominant with Scots pine (Pinus sylvestris L.). Mature oaks are $2-5 \mathrm{~m}$ tall at the dry site, and $4-12 \mathrm{~m}$ at the reference site and crown cover is lower at Salgesch. Pictures illustrating the physiognomy of the two sites can be found in Fig. 2 of Zweifel et al. (2009).

Because biomass allocation is more dependent on size than on age (Coleman et al. 1994; Weiner 2004; Martinez-Vilalta et al. 2007), we compared stressed trees with reference trees of similar size. Climate data were obtained from the nearby national meteorological station of Sion (MeteoSwiss: 46 $13^{\prime} 11 \mathrm{~N}, 7^{\circ} 19^{\prime} 36 \mathrm{E}$; Table S1). Total precipitation from March to June was used to test the correlation of precipitation with ring width series, because these months are most influential for radial growth of $Q$. pubescens in this area (Zweifel et al. 2006).

\section{Tree sampling}

At the end of the 2004 growing season, eight oaks of 2-4 $\mathrm{m}$ height were harvested, four at the dry site and four at the reference site. Due to the relative inaccessibility of the site, neither hydraulic nor air-jet excavation was possible, so we carefully excavated all roots $>0.5 \mathrm{~cm}$ in diameter by hand for two trees per site, manual root excavation of adult trees in rocky soil being too labor intensive to complete for all trees. From every branch of these four trees a disc was taken at $10 \mathrm{~cm}$ radial distance from the stem. The stem was cut in segments and at every $50 \mathrm{~cm}$ a disc was taken. The primary root was cut in slices of $2-5 \mathrm{~cm}$ thick. Discs from the secondary roots were taken at every 20 or $50 \mathrm{~cm}$, depending on the diameter variation. Disc circumference and length were determined to calculate wood volume. The four trees from which we could not extract roots were used for analysis of height growth and aboveground biomass allocation only. For each tree all leaves were oven dried at $70{ }^{\circ} \mathrm{C}$ for $>96 \mathrm{~h}$ and total leaf dry mass was determined. 
Tree ring measurements

Surfaces of all discs were polished (up to sandpaper grit 800), or prepared with a razor blade to make ring boundaries clearly visible. Ring numbers were counted on all discs. Ring widths were measured for discs from stems and primary roots using a binocular microscope, and were recorded in TSAPWin (Rinn 2003) and plotted as time series. To trace partly missing rings and to cross-date ring width series, we first derived reference ring width series for the eight oaks from the samples taken at the stem base. Discs from the primary root were measured using these reference series and, one by one, lower discs were cross-dated. Rings of secondary root discs were only counted, as the increasingly diffuse-porous structure and vague ring boundaries, common for deeper roots (Drexhage et al. 1999; Gärtner 2007), made accurate quantification of ring width impossible.

Volume and biomass calculations

To estimate volume and mass the $50-\mathrm{cm}$ stem segments were considered truncated cones, and the top segment a full cone. Stem mass was calculated as:

Stem mass $(\mathrm{g})=(0.79)$

$$
\times\left[\sum_{i=1}^{n-1}\left(\frac{1}{3} \cdot \pi \cdot h \cdot\left(r_{1}^{2}+r_{1} \cdot r_{\mathrm{u}}+r_{\mathrm{u}}^{2}\right)\right)+\left(\frac{1}{3} \cdot \pi \cdot h \cdot r_{1}^{2}\right)\right]
$$

where 0.79 is the average wood density of $Q$. pubescens trees at this site [determined with the water replacement method for bark-free stem discs taken at $1 \mathrm{~m}$ height from ten trees (Sterck et al., unpublished data)]; $n$ is the number of stem segments, including the top segment; $h$ is the height of the segment in $\mathrm{cm}$; and $r_{1}$ and $r_{\mathrm{u}}$ are the radii in $\mathrm{cm}$ of the lower and upper cross sections of the segments, respectively. Wood density of $0.79 \mathrm{~g} / \mathrm{cm}^{3}$ is in the high range of values published for this species, but not uncommon for trees growing under dry conditions high on hill slopes (Barij et al. 2007).

To estimate biomass investment in root, stem, and branches in the growing season before the trees were harvested (2004), the estimated volume of wood that had accumulated until 2003 was subtracted from the estimated volume of wood at harvest, and mass was calculated from wood volume as above. Branches were not divided in segments, so the 2004 biomass investment in branches was calculated as: [(year ring area $\left._{2004}\right) /($ total cross-section area) $] \times($ branch mass) and then summed across all branches.

Statistical analyses

Parameters of stressed and reference trees were compared using Wilcoxon rank-sum tests. Correlations between stem and root ring width chronologies, and between ring width and precipitation, were analyzed with Spearman's rho. Analyses were performed in R version 2.6.0 (R Development Core Team 2007) or JMP 8 (SAS Institute, Cary, NC, USA).

\section{Results and discussion}

Tree status

Stressed trees were older, had a larger diameter at breast height, and had higher total biomass than reference trees at comparable tree height (Table 1). The major portion of the below-ground biomass was located immediately below the trunk base, as previously described in Di Iorio et al. (2005). Primary roots of stressed trees were not only thicker than the stem just above the soil surface; they were also older (Table 1). These older primary roots supported greater biomass of secondary roots than primary roots of reference trees did (Fig. 1). Thus, in line with hypothesis 1, droughtstressed trees maintained proportionally more biomass in roots and less in stems and branches than reference trees (Fig. 1). This finding supports the functional equilibrium hypothesis and suggests that in water-limited conditions proportionally more resources must be invested in roots to maintain a given aboveground biomass (Litton et al. 2007).

Interestingly, in contradiction with hypothesis 2 , in the very dry 2004 growing season stressed trees allocated a much larger proportion of aboveground biomass to leaves, and a smaller proportion to wood than reference trees $(P<0.05$; Fig. 1b). Ring width and growing season precipitation were significantly correlated for both stems and roots of stressed trees (all $P<0.1$ ), but not for reference trees. Furthermore, a strong correlation existed between annual diameter growth of stems and roots $(P<0.05$; Fig. 2). These correlations suggest that in contrast to hypothesis 3 , years with relatively high precipitation did not see preferential biomass investment in aboveground structures.

In the following, we will first describe the detected growth patterns and then discuss those results in light of our central hypotheses.

\section{Growth history}

We distinguished three growth phases for the stressed trees (Fig. 3a, b). In phase I (ca. 25 years), aboveground structures did not persist, suggesting that the shoots died back, possibly repeatedly, between 1935 and 1960. This may have occurred as a result of biotic disturbances, such as browsing by goats or stem harvest for viniculture (Gimmi and Bürgi 2007; Gimmi et al. 2010). Consequently, the 
Table 1 Overview of height, age, diameter at breast height (DBH) and biomass of stressed and reference (Ref.) Q. pubescens trees harvested from the Valais, Switzerland

\begin{tabular}{|c|c|c|c|c|c|c|c|c|c|c|c|c|c|c|c|}
\hline \multirow[t]{2}{*}{ Tree } & \multirow[t]{2}{*}{ Site } & \multicolumn{2}{|c|}{ Age (year) } & \multirow[t]{2}{*}{$\mathrm{DBH}(\mathrm{cm})$} & \multirow[t]{2}{*}{ Height (m) } & \multicolumn{5}{|c|}{ Biomass $(\mathrm{kg})$} & \multicolumn{5}{|c|}{ Biomass investment 2004 (g) } \\
\hline & & $H_{-0.10}$ & $H_{0.0}$ & & & Root & Stem & Branch & Leaf $^{b}$ & Total & Root & Stem & Branch & Leaf $^{b}$ & Total \\
\hline $\mathrm{S} 1$ & Dry & 67 & 51 & 6.4 & $3.6^{\mathrm{a}}$ & 12 & 12 & 3.3 & 1.2 & 28.5 & 73 & 274 & 289 & 1,875 & 2,511 \\
\hline $\mathrm{S} 2$ & Dry & 71 & 42 & 4.5 & $2.9^{\mathrm{a}}$ & 7 & 6 & 1.7 & 0.4 & 15.1 & 17 & 62 & 62 & 418 & 559 \\
\hline $\mathrm{S} 3$ & Dry & & 42 & 3.9 & $2.7^{\mathrm{a}}$ & & 4 & $2.8^{\mathrm{b}}$ & 0.4 & & & 65 & & 445 & \\
\hline S4 & Dry & & 53 & 2.7 & $2.5^{\mathrm{a}}$ & & 3 & $1.2^{\mathrm{b}}$ & 0.3 & & & 22 & & 257 & \\
\hline R1 & Ref. & 18 & 15 & 1.4 & 2.9 & 1 & 2 & 0.8 & 0.4 & 4.2 & 101 & 279 & 151 & 441 & 972 \\
\hline $\mathrm{R} 2$ & Ref. & 14 & 13 & 3.5 & 3.4 & 3 & 2 & 1.7 & 1.2 & 7.9 & 244 & 433 & 376 & 1,166 & 2,219 \\
\hline R3 & Ref. & & 15 & 2.3 & 2.3 & & 2 & $2.2^{\mathrm{b}}$ & 0.5 & & & 101 & & 450 & \\
\hline $\mathrm{R} 4$ & Ref. & & 13 & 2.4 & 3.9 & & 4 & $2.3^{\mathrm{b}}$ & 1.2 & & & 444 & & 1,169 & \\
\hline
\end{tabular}

$H_{-0.10}, H_{0.0}$ height of the discs in the tree, respectively at $0.10 \mathrm{~m}$ below, and at the soil surface

${ }^{a}$ Height from soil surface to highest branch

${ }^{\mathrm{b}}$ Weighed values (not calculated)

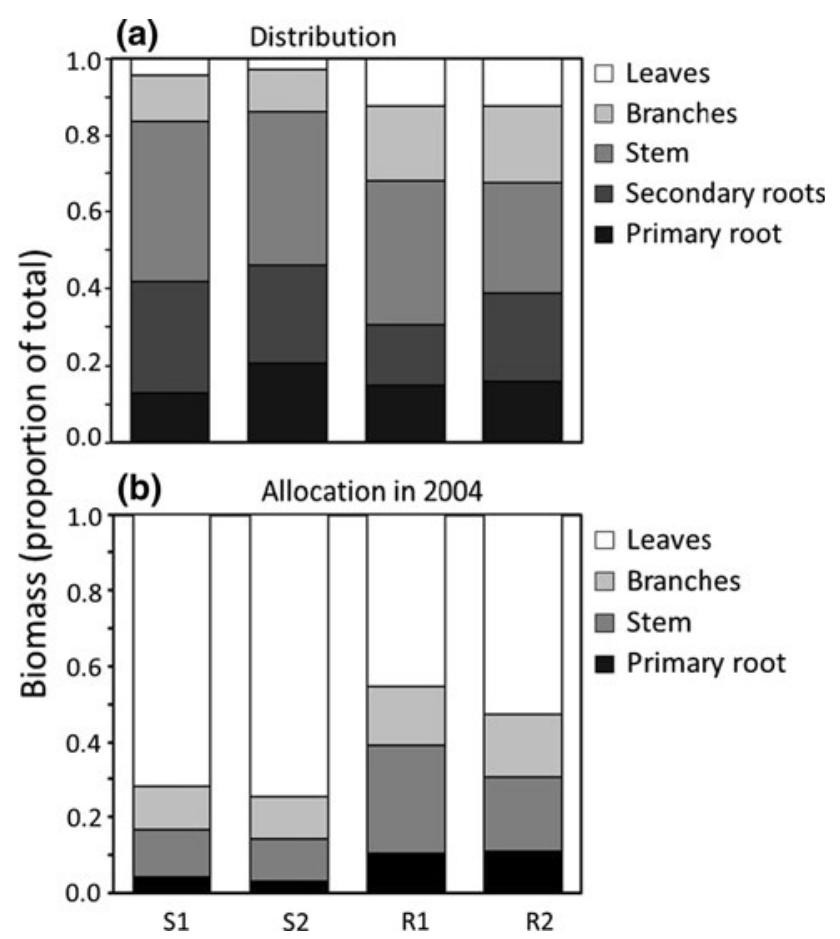

Fig. 1 Proportional distribution of biomass (a) and allocation to leaves, branches, stem, and roots in the 2004 growing season (b) of two drought-stressed $Q$. pubescens trees $(S 1, S 2)$ and two reference trees $(R 1, R 2)$. Secondary roots are only included in the biomass distribution graph, as ring width could not be determined on discs from secondary roots

primary roots were older than the stems just above the surface (Table 1). Other oak species have also been shown to have older roots than stems when grown in harsh environments (Johnson et al. 2002), highlighting the capacity of this genus to withstand harsh conditions by re-sprouting following stem dieback. Dieback may also have been caused by frost or summer drought, both of which commonly occur in the area. Because browsing, stem harvesting, drought, and frost can all cause dieback of stems, we cannot make inferences about the causes of aboveground dieback in phase I, and only note the effect, namely, buildup of below-ground biomass, rich in reserves.

Phase II lasted another 25 years ( 1960 to 1985). In this period trees grew in height and produced almost all the secondary roots that persisted until tree harvest in 2004 (Fig. 3a, b). The height growth rate of $10( \pm 3) \mathrm{cm}$ per year (mean $\pm 1 \mathrm{SD}$ ) during this phase was significantly lower than height growth rate in reference trees $(23 \pm 3 \mathrm{~cm})$ (Wilcoxon rank-sum test for comparison of the slopes of the linear part of the phase II height growth curves of all eight trees $(P<0.05$; Fig. $3 \mathrm{c}$, d). The decline in goat numbers and stem harvest in Valais between 1950 and 1970 (Rigling et al. 2006; Gimmi and Bürgi 2007) could explain why the stressed oaks produced a persistent stem only from 1960 onward.

In phase III net height growth and production of persisting secondary roots ceased. The stressed trees did not get taller than 3-4 m, most likely a result of hydraulic limitation (Ryan et al. 2006), as suggested by earlier studies of $Q$. pubescens in Valais (Weber et al. 2007; Zweifel et al. 2007). Reference trees only had phase II-type growth (Fig. 3).

These height growth patterns were strongly associated with the dynamics of radial growth of stems and roots. In phase I, radial growth of the primary roots was comparatively stable (Fig. 3). Ring widths of primary roots peaked in phase II and then gradually declined again in phase III. Most secondary roots developed in phase II. Coutts and Nicoll (1991) found that taproot growth generally slows down as growth of secondary roots increases. In the drought-stressed trees in our study this was clearly not the case (Fig. 3). The aboveground development in phase II 
Fig. 2 Ring width of stems (bold black line) and roots (bold grey line) (left axis) plotted as time series. Solid lines represent annual variations; dashed lines represent the 10-year moving averages. On the secondary $y$ axis the precipitation between March and June for each year (solid grey line) and its 10-year moving average (dashed grey line) are plotted
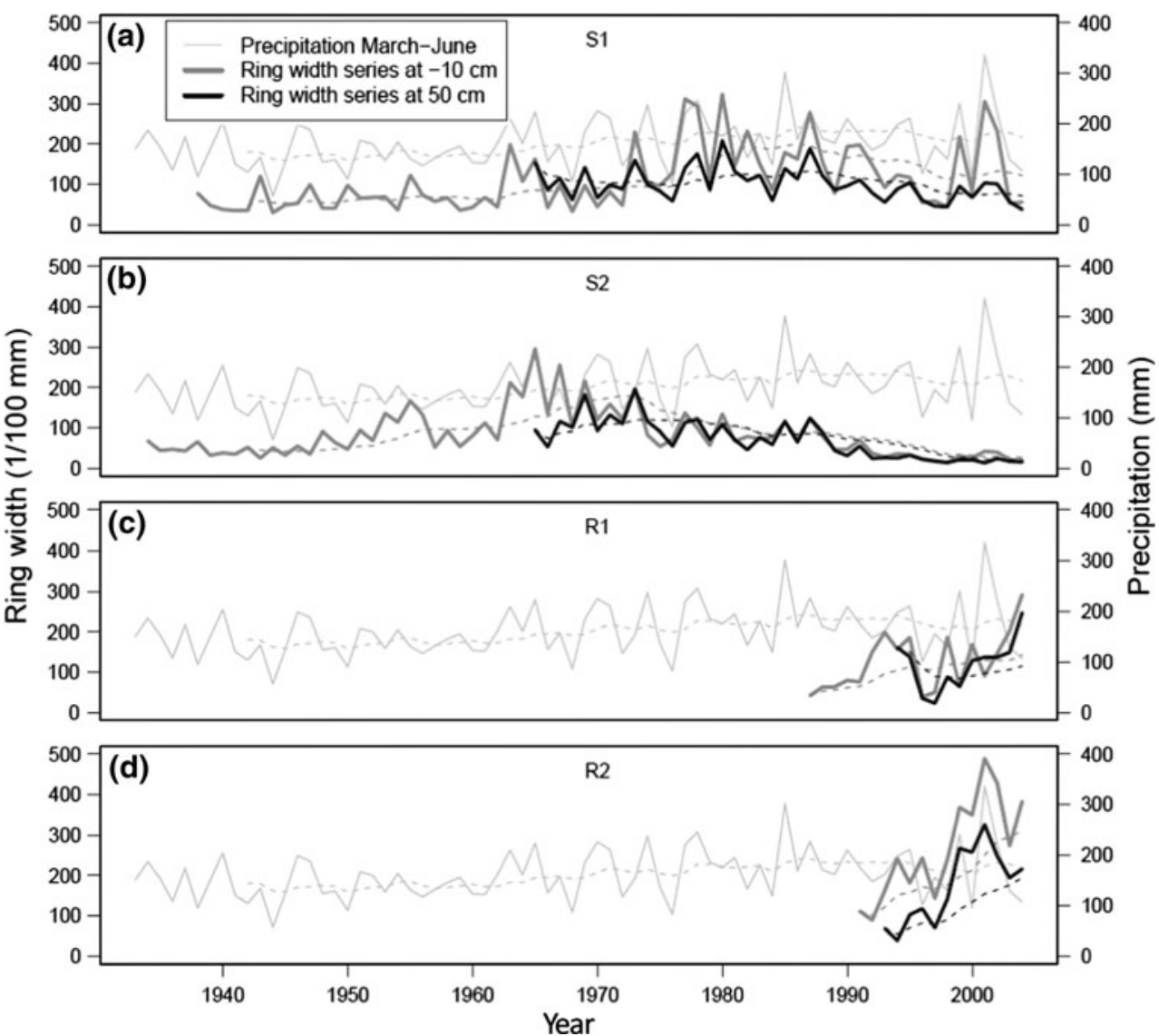

and the maintenance of a canopy presumably generated sufficient energy for extensive secondary roots to develop; at the same time the primary root was probably used for carbohydrate storage (e.g., Barbaroux et al. 2003). Hydraulic limitation may have prevented further height growth at any given year and investment in below-ground storage would thus have been beneficial (Bloom et al. 1985; Chapin et al. 1990).

Interestingly, radial growth of the primary root in phases II and III was strongly correlated with the radial growth of the stem for all trees (all $P<0.01$; Fig. 2). Correlations between radial growth of roots and stems were also found for other temperate tree species that were harvested from more mesic woodlands, including several oak species (Krause and Eckstein 1993; Drexhage et al. 1999). The correlations between radial growth of both stems and roots of stressed trees and growing season precipitation were strong when analyzed for the period of active height growth (phase II in Fig. 3) $(P<0.05)$, but weaker $(P<0.1)$ when calculated over the whole period of aboveground growth (phases II and III). For reference trees ring width did not correlate with growing season precipitation, supporting the notion that growth was indeed not as limited by water availability as at the dry site (Zweifel et al. 2009). The ring width-precipitation correlations of stressed trees confirm that better growth conditions result in higher biomass investments in both below-ground and aboveground wood, and not in preferential investment in aboveground structures.

We hypothesized that drought-stressed trees would have proportionally more root and less shoot mass than reference trees as a response to greater limitation of belowground resources, and indeed our data supported this hypothesis (Fig. 1). We further hypothesized that stressed trees would allocate more biomass to aboveground wood and less to leaves than reference trees to minimize the risk of hydraulic failure (Sterck et al. 2008; Zweifel and Zeugin 2008; Galle et al. 2010). However, the opposite was true: in the very dry 2004 growing season, stressed trees invested a greater biomass fraction in leaves than reference trees (Fig. 1). Early season growth of leaves (Wardlaw 1990) and twigs (Bréda et al. 2006) is supported by carbohydrate reserves, so current season growth is affected by the previous growing season. The 2003 growing season was extremely warm and dry (Ciais et al. 2005). Severe drought suppresses photosynthesis in $Q$. pubescens and consequent depletion of carbohydrate storage reduces foliage growth in the subsequent growing season in saplings (Galle et al. 2010). Nevertheless, the proportional allocation to leaves in 2004 was greater in stressed trees than in reference trees. 

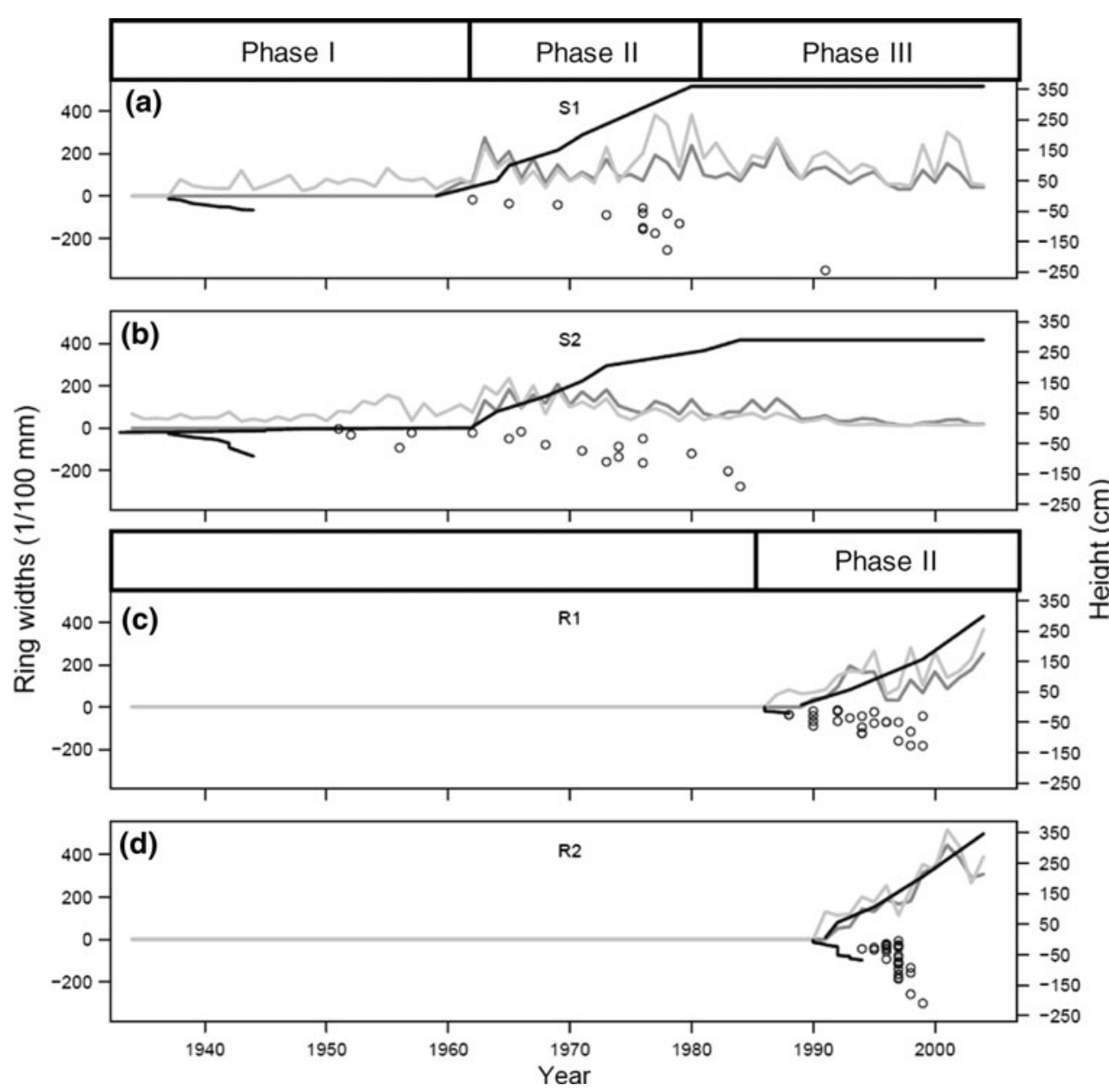

Fig. 3 Annual ring width (light grey lines primary roots, dark grey lines stems), and height (black lines) of stressed (a, b) and reference (c, d) $Q$. pubescens trees. Height in this figure refers to the highest position along the stem at which side branches were present. Actual height could not be determined for every point in time, but using the age of branches at different heights the height growth pattern was reconstructed. Using height of the highest branch means that total tree height is necessarily slightly underestimated. Height growth of stressed oaks ceased 25 years prior to harvest and a clear top shoot

These stressed oaks have lower stomatal (Zweifel et al. 2009) and stem hydraulic conductance (Sterck et al. 2008) and therefore greater water use efficiency (Field et al. 1983) than reference oaks. This might enable stressed trees to invest more in leaves when less water acquisition and transport structures would be required per unit leaf area to replace transpired water. An additional explanation could be that high leaf investments enable stressed trees to enhance carbon gain during short, relatively wet periods in the early growing season. Damesin and Rambal (1995) found that $Q$. pubescens trees cope with summer drought by concentrating photosynthetic production in the less dry spring season. Such a strategy might be at the cost of higher risks of cavitation and low carbon gain during dry periods (Cannell and Dewar 1994; Nardini and Pitt 1999; was missing. Hence, the line representing total height is horizontal from the point where the highest branch was recorded. Growth of the primary root is shown as negative height growth. Circles indicate the distance of secondary roots from the soil surface (measured along the root) in the year they first appeared. The tips of excavated roots were all $>1$ year old, so although no coarse roots developed in recent years, we cannot conclude that root growth had ceased altogether. For the stressed oaks, the three phases of growth (see body text) are indicated

Sterck et al. 2008), because $Q$. pubescens is not drought deciduous. Wood anatomical adjustment in response to drought, as observed for $Q$. pubescens trees at this site, does, however, help minimize risk of hydraulic failure even during severe summer drought (Galle et al. 2010).

Our third hypothesis also has to be rejected: we did not find preferential investment below ground during dry years and above ground during wetter years. Cannell and Dewar (1994) suggested that decreased stomatal resistance should result in decreased allocation to water acquisition. Oak trees at the dry site have higher stomatal resistance than at the reference site (Zweifel et al. 2009) and do maintain proportionally more root biomass, but our dendrochronological reconstruction shows that decreased stomatal resistance in wetter years does not result in a decrease in 
root growth. Axelsson and Axelsson (1986) also found that although drought (of $P$. silvestris trees) reduced photosynthesis (presumably through increased stomatal resistance) the effects on biomass partitioning were small. Possibly, sub-seasonal dry spells triggered temporary shifts in allocation patterns, but across growing seasons such a pattern did not exist. To better understand the plasticity of biomass allocation and its role in maintenance of functional homeostasis of trees under water stress conditions quantification of seasonal or annual investment of biomass in leaves and fine roots will be necessary (Magnani et al. 2000).

We used stem analysis at the whole-tree level to assess growth and distribution of biomass in $Q$. pubescens trees at two sites with different water availability. Disentangling biotic and abiotic factors from ontogenetic ones remains challenging. Size matching for comparing biomass allocation patterns between trees with different growth rates creates an inherent problem: trees have developed in different time windows characterized by specific conditions, including changes in management practices, or even climate change (e.g. Carnicer et al. 2011). Our study included a limited number of root systems, extracted from one very dry site, so generalizations about the lifetime growth patterns of "dry woodland trees" cannot be made. However, the approach chosen illustrates how mature trees allocated biomass and maintained functional balance in response to multiple stresses, whether biotic or abiotic, during their lives, something that is not easily studied in controlled experiments. Our method further enabled us to show that radial growth in both roots and stems is driven by water availability for $Q$. pubescens trees at the study site, whereas growth of reference trees was less driven by water availability, at least at the annual scale.

We conclude that the growth responses of trees beyond seedling stage are different from those of seedlings, and that this can be analyzed successfully using whole-tree stem analysis. The analysis of sub-seasonal patterns in growth and biomass allocation would, however, require additional techniques.

Acknowledgments We thank Simone de Brock, Alfred Chitiki, Qumruzzaman Chowdhury and Marijn de Zwart for conducting fieldwork. Britta Eilmann advised on tree-ring analysis. U.S.-K. received funds from the NWO/MEERVOUD program (NWO/AWL 836.05.030). Two anonymous reviewers are gratefully acknowledged for their insightful comments on an earlier version of this manuscript.

\section{References}

Axelsson E, Axelsson B (1986) Changes in carbon allocation patterns in spruce and pine trees following irrigation and fertilization. Tree Physiol 2:189-204. doi:10.1093/treephys/2.1-2-3.189
Barbaroux C, Bréda N, Dufrêne E (2003) Distribution of aboveground and below-ground carbohydrate reserves in adult trees of two contrasting broad-leaved species (Quercus petraea and Fagus sylvatica). New Phytol 157:605-615. doi:10.1046/j. 1469-8137.2003.00681.x

Barij N, Stokes A, Bogaard T, van Beek LPH (2007) Does growing on a slope affect tree xylem structure and water relations? Tree Physiol 27:757-764. doi:10.1093/treephys/27.5.757

Bloom AJ, Chapin FS III, Mooney HA (1985) Resource limitation in plants: an economic analogy. Annu Rev Ecol Syst 16:363-392. doi:10.1146/annurev.es.16.110185.002051

Bréda N, Huc R, Granier A, Dreyer E (2006) Temperate forest trees and stands under severe drought: a review of ecophysiological responses, adaptation processes and long-term consequences. Ann For Sci 63:625-644. doi:10.1051/forest:2006042

Brouwer R (1962) Distribution of dry matter in the plant. Neth J Agric Sci 10:361-376

Cannell MGR, Dewar RC (1994) Carbon allocation in trees: a review of concepts for modelling. Adv Ecol Res 25:59-104. doi: 10.1016/S0065-2504(08)60213-5

Carnicer J, Coll M, Ninyerola M, Pons X, Sanchez G, Peñuelas J (2011) Widespread crown condition decline, food web disruption, and amplified tree mortality with increased climate changetype drought. Proc Natl Acad Sci USA 108:1474-1478. doi: 10.1073/pnas. 1010070108

Chapin FS III, Schulze E-D, Mooney HA (1990) The ecology and economics of storage in plants. Annu Rev Ecol Syst 21:423-447. doi:10.1146/annurev.es.21.110190.002231

Ciais P, Reichstein M, Viovy N, Granier A, Ogee J, Allard V, Aubinet M, Buchmann N, Bernhofer C, Carrara A, Chevallier F, De Noblet N, Friend AD, Friedlingstein P, Grunwald T, Heinesch B, Keronen P, Knohl A, Krinner G, Loustau D, Manca G, Matteucci G, Miglietta F, Ourcival JM, Papale D, Pilegaard K, Rambal S, Seufert G, Soussana JF, Sanz MJ, Schulze E-D, Vesala T, Valentini R (2005) Europe-wide reduction in primary productivity caused by the heat and drought in 2003. Nature 437:529-533. doi:10.1038/nature03972

Coleman JS, McConnaughay KDM, Ackerly DD (1994) Interpreting phenotypic variation in plants. Trends Ecol Evol 9:187-191. doi: 10.1016/0169-5347(94)90087-6

Coutts MP, Nicoll BC (1991) Orientation of the lateral roots of trees. I. Upward growth of surface roots and deflection near the soil surface. New Phyt 119:227-234. doi:10.1111/j.1469-8137. 1991.tb01025.x

Damesin C, Rambal S (1995) Field study of leaf photosynthetic performance by a Mediterranean deciduous oak tree (Quercus pubescens) during a summer drought. New Phytol 131:159-167. doi:10.1111/j.1469-8137.1995.tb05717.x

DeWitt TJ, Sih A, Wilson DS (1998) Costs and limits of phenotypic plasticity. Trends Ecol Evol 13:77-81. doi:10.1016/S0169-5347 (97)01274-3

Di Iorio A, Lasserre B, Scippa GS, Chiatante D (2005) Root system architecture of Quercus pubescens trees growing on different sloping conditions. Ann Bot 95:351-361. doi:10.1093/aob/ mci033

Drexhage M, Huber F, Colin F (1999) Comparison of radial increment and volume growth in stems and roots of Quercus petraea. Plant Soil 217(1-2):101-110. doi:10.1023/A:100464 7418616

Fayle DCF (1975) Extension and longitudinal growth during the development of red pine root systems. Can J For Res 5:109-121. doi:10.1139/x75-016

Field C, Merion J, Mooney HA (1983) Compromises between wateruse efficiency and nitrogen-use efficiency in five species of California evergreens. Oecologia 60:384-389. doi:10.1007/ BF00376856 
Galle A, Esper J, Feller U, Ribas-Carbo M, Fonti P (2010) Responses of wood anatomy and carbon isotope composition of Quercus pubescens saplings subjected to two consecutive years of summer drought. Ann For Sci 67:809. doi:10.1051/forest/ 2010045:MSNr809

Gärtner H (2007) Tree roots-methodological review and new development in dating and quantifying erosive processes. Geomorphology 86:243-251. doi:10.1016/j.geomorph.2006.09.001

Gimmi U, Bürgi M (2007) Using oral history and forest management plans to reconstruct traditional non-timber forest uses in the Swiss Rhone valley (Valais) since the late nineteenth century. Environ Hist 13(2):211-246. doi:10.3197/096734007780473492

Gimmi U, Wohlgemuth T, Rigling A, Hoffmann CW, Bürgi M (2010) Land-use and climate change effects in forest compositional trajectories in a dry Central-Alpine valley. Ann For Sci 67:701. doi:10.1051/forest/2010026:MSNr701

Johnson PS, Shifley SR, Rogers R (2002) Regeneration ecology II: population dynamics. In The ecology and silviculture of oaks. CABI Publishing, Wallingford, UK

Krause C, Eckstein D (1993) Dendrochronology of roots. Dendrochronologia 11:9-23

Litton CM, Raich JW, Ryan MG (2007) Carbon allocation in forest ecosystems. Glob Change Biol 13(10):2089-2109. doi: 10.1111/j.1365-2486.2007.01420.x

Magnani F, Mencuccini M, Grace J (2000) Age-related decline in stand productivity: the role of structural acclimation under hydraulic constraints. Plant, Cell Environ 23:251-263. doi: 10.1046/j.1365-3040.2000.00537.x

Markesteijn L, Poorter L (2009) Seedling root morphology and biomass allocation of 62 tropical tree species in relation to drought- and shade-tolerance. J Ecol 97:311-325. doi:10.1111/j. 1365-2745.2008.01466.x

Martinez-Vilalta J, Korakaki E, Vanderklein D, Mencuccini M (2007) Below-ground hydraulic conductance is a function of environmental conditions and tree size in Scots pine. Funct Ecol 21(6):1072-1083. doi:10.1111/j.1365-2435.2007.01332.x

McConnaughay KDM, Coleman JS (1999) Biomass allocation in plants: ontogeny or optimality? A test along three resource gradients. Ecology 80:2581-2593. doi:10.1890/0012-9658(1999) 080[2581:BAIPOO]2.0.CO;2]

Nardini A, Pitt F (1999) Drought resistance of Quercus pubescens as a function of root hydraulic conductance, xylem embolism and hydraulic architecture. New Phytol 143:485-493. doi:10.1046/j. 1469-8137.1999.00476.x

Niinemets Ü (2010) Responses of forest trees to single and multiple environmental stresses from seedlings to mature plants: past stress history, stress interactions, tolerance and acclimation. For Ecol Manage 260:1623-1639. doi:10.1016/j.foreco.2010.07.054

R Development Core Team (2007) R: a language and environment for statistical computing. R Foundation for Statistical Computing, Vienna
Rigling A, Bräker O, Schneiter G, Schweingruber F (2002) Intraannual tree-ring parameters indicating differences in drought stress of Pinus sylvestris within the Erico-Pinion in the Valais (Switzerland). Plant Ecol 163(1):105-121. doi:10.1023/A: 1020355407821

Rigling A, Dobbertin M, Bürgi M, Gimmi U, Graf Pannatier E, Gugerli F, Heiniger U, Polomski J, Rebetez M, Rigling D, Weber P, Wermelinger B, Wohlgemuth T (2006) Verdrängen Flaumeichen die Walliser Waldförhen? Merkbl Prax 41:16

Rinn F (2003) TSAP-Win user reference (version 0.53). RinnTech, Heidelberg

Ryan MG, Phillips N, Bond BJ (2006) The hydraulic limitation hypothesis revisited. Plant, Cell Environ 29(3):367-381. doi: 10.1111/j.1365-3040.2005.01478.x

Sack L, Grubb PJ (2002) The combined impacts of deep shade and drought on the growth and biomass allocation of shade-tolerant woody seedlings. Oecologia 131:175-185. doi:10.1007/s00442002-0873-0

Sterck FJ, Zweifel R, Sass-Klaassen U, Chowdhury Q (2008) Persisting soil drought reduces leaf specific conductivity in Scots pine (Pinus sylvestris) and Pubescent oak (Quercus pubescens). Tree Physiol 28(4):529-536

Tyree MT, Zimmermann MH (2002) Hydraulic architecture of whole plants and plant performance. In: Xylem structure and the ascent of sap, 2nd edn. Springer, New York, pp 175-205

Wardlaw IF (1990) Tansley Review No 27. The control of carbon partitioning in plants. New Phytol 116:341-381. doi:10.1111/j. 1469-8137.1990.tb00524.x

Weber P, Bugmann H, Rigling A (2007) Radial growth responses to drought of Pinus sylvestris and Quercus pubescens in an innerAlpine dry valley. J Veg Sci 18(6):777-792

Weiner J (2004) Allocation, plasticity and allometry in plants. Perspect Plant Ecol Evol Syst 6(4):207-215. doi:10.1078/14338319-00083

Zweifel R, Zeugin F (2008) Ultrasonic acoustic emissions in droughtstressed trees-more than signals from cavitation? New Phytol 179(4):1070-1079. doi:10.1111/j.1469-8137.2008.02521.x

Zweifel R, Zimmermann L, Zeugin F, Newbery DM (2006) Intraannual radial growth and water relations of trees: implications towards a growth mechanism. J Exp Bot 57(6):1445-1459. doi: 10.1093/jxb/erR125

Zweifel R, Steppe K, Sterck FJ (2007) Stomatal regulation by microclimate and tree water relations: interpreting ecophysiological field data with a hydraulic plant model. J Exp Bot 58(8):2113-2131. doi:10.1093/jxb/erm050

Zweifel R, Rigling A, Dobbertin M (2009) Species-specific stomatal response of trees to drought-a link to vegetation dynamics? J Veg Sci 20:442-454. doi:10.1111/j.1654-1103.2009.05701.x 